\title{
Analysis of BRAF V600E Mutation in Gastrointestinal Malignant Melanomas
}

\section{Gastrointestinal Malign Melanomlarda BRAF V600E Mutasyon Analizi}

\author{
Hayriye Tatlı Doğan, Merve Meryem Kıran \\ Ankara Yıldırım Beyazıt Üniversitesi, Atatürk Eğitim ve Araştırma Hastanesi, Patoloji Ana Bilim Dalı, Ankara
}

Dergiye Ulaşma Tarihi: 05.10.2017 Dergiye Kabul Tarihi: 23.10.2017 Doi: 10.5505/aot.2018.95967

\begin{abstract}
ÖZET
GíRIŞ ve AMAÇ: Gastrointestinal mukozal malign melanomlarda BRAFV600E mutasyon varlığı ve olguların klinik özelliklerini incelemeyi amaçladık.

YÖNTEM ve GERECLLR: Ankara Yıldırım Beyazıt Üniversitesi Atatürk Eğitim ve Araştırma Hastanesi Patoloji bölümünde 2006-2015 yılları arasında tanı almış malign melanomlar retrospektif olarak taranarak mukozal melanomlar ve bunlar içerisinden gastrointestinal malign melanom olguları elde edilmiş ve arşiv bloklarından hazırlanan kesitlerde gerçek zamanlı PCR yöntemi ile BRAFV600E mutasyonu araştırılmıştır. Aynı zamanda bu olguların klinik özellikler gözden geçirilmiştir.

BULGULAR: Mukozal Malign Melanom tanısı alan 14 olgunun 6'sı gastrointestinal yerleşimli idi. Bu olgular 54-84 yaş aralığında olup tümör 4'ü rektum, 2'si ince barsak lokalizasyona sahipti. Olguların tamamında PCR yöntemi ile çalışılan BRAF-V600E mutasyonu yalnızca ince barsak yerleşimli ve omentum metastazı olan 1 olguda izlenmiştir.
\end{abstract}

TARTIŞMA ve SONUÇ: BRAF-V600E mutasyonu var olan tek olguda tümör multi odaklar halinde gelişim göstermiş olup bu nedenle mukozal metastaz düşünülmüştür. Primer kutanöz ve oküler melanomlar gastrointestinal sisteme sık olarak metastaz yapabilmektedir. Ancak primer odağı saptamak her zaman mümkün olmayabilir. Primer gastrointestinal melanomlar da çok nadir olup genetik açıdan da kutanöz melanomlardan farklı özellikler içerebilir.

Anahtar Kelimeler: Gastrointestinal, melanom, BRAFV600E mutasyonu

\begin{abstract}
INTRODUCTION: We aimed to investigate BRAF V600E mutation in gastrointestinal mucosal melanomas and patients' clinical outcomes.

METHODS: The melanomas which were diagnosed at Ankara Yıldırım Beyazıt University/ Atatürk Education and Research Hospital between 2006 and 2015 were retrospectively screened for mucosal melanomas. Gastrointestinal malignant melanomas were obtained from these cases. BRAF V600E mutation analysis is performed to a total of 6 gastrointestinal melanoma cases by real time PCR method. In addition clinical characteristics of these cases have beeen reviewed.

RESULTS: Six of the 14 patients with mucosal melanoma were gastrointestinal. There were cases of rectum and 2 cases of small bowel, and patients were between 54- 84 years. BRAF V600E mutation was detected in one of the small bowel localized case with omentum metastasis.

DISCUSSION AND CONCLUSION: The only case with BRAF V600E mutation was multifocal therefore mucosal metastatis is considered in this case. Primary cutaneous and ocular melanomas can frequently metastasize to the gastrointestinal tract. However, it may not always be possible to identify the primary tumor. Primary gastrointestinal melanomas are very rare and genetically different from cutanous melanomas.
\end{abstract}

Keywords: Gastrointestinal, melanoma, BRAF V600E mutation 


\section{Gİis}

Melanomlar solar ultraviyole (UV) 1 şık maruziyetine bağlı gelişen kutanöz deri kanserlerinin letal bir formudur (1). Melanomlar tüm malignitelerin \%1-3 kadarını oluşturur (2).

Kutanöz formları yanı sıra izlenebilen mukozal malign melanomlar; kutanöz formlardan farklı klinik ve patolojik karakteristiğe sahip, agresif gidişli neoplazilerdir (3). Primer mukozal malign melanomlar oral kavite, sinonazal pasaj, vulvavajina, anorektal bölge ve üriner sistemde izlenebilir (4). Vulvar melanomlar milyonda 1.2 oranında, baş-boyun bölgesi melanomları milyonda 0.7 oranında, anorektal melanomlar milyonda 0.4 oranında, vajinal melanomlar milyonda 0.3 oranında ve penil melanomlar milyonda 0.1 oranında görülme sıklığına sahiptirler (3).

Melanomlar gastrointestinal sisteme en s1k metastaz yapan tümörlerdir (4). Kutanöz ve oküler lezyonların metastazları gastrointestinal sistemde sıkça görülür. $\mathrm{Bu}$ melanomların metastazları en sik ince barsakta izlenirken, ince barsakta ortaya çıkan melanomların yalnızca \%2'si primer barsak kökenlidir (4).

Kutanöz melanomlarında ultraviyole (UV) 1şık maruziyeti büyük bir risk faktörü iken mukozal melanomlarda hastalığa ait risk faktörleri henüz tanımlanmamıştır (5). Sinonazal mukozal melanomlarda formaldehid maruziyetinin risk faktörü olabileceği yönünde yayınlar mevcuttur (5).

Kutanöz melanomların nöral krest kaynaklı melanositlerden geliştiği, nonkutanöz melanomların ise melanoblastlardan köken aldığ 1 düşünülmektedir $(3,4)$. İnce barsakta gelişen primer malign melanomun melanoblastlar, schwannian nöroblastik hücreler veya APUD hücrelerinin transformasyonu sonucu oluştuğu yönünde görüşler mevcuttur $(4,6)$.

Melanomlar oldukça heterojen bir grup tümör olup mukozal ve kutanöz melanomlar farklı genetik yolaklar içerirler $(3,4,7)$. Kutanöz melanomlarda en s1k BRAF (serin/treonin kinaz) mutasyonu görülürken mukozal melanomlarda siklıkla c-kit mutasyonu izlenir $(3,5,7)$.
BRAF, 7q 34'de lokalize MAPK(mitojen aktive edici protein kinaz) yolağının üyesi bir serin/treonin kinazdır (8). En sik BRAFV600E mutasyonu izlenirken ardından \%10-30 oraninda BRAF-V600K mutasyonu, \%3 oranında $\mathrm{V} 600 \mathrm{D} / \mathrm{R}$ mutasyonu görülür (9). BRAF-V600E mutasyonu melanom hücrelerinde ERK aktivitesini sağlayarak hücrelerin kontrolsüz proliferasyonunu etkiler (7). Kutanöz ve özellikle mukozal melanomlarda c-kit aktivasyonu ile MAPK yolağ1 üzerinden hücrelerde kontrolsüz proliferasyon görülmektedir $(5,7)$. Ayrıca mukozal melanomlarda RAS kaskadının üyesi HRAS, NRAS, KRAS mutasyonlar1 izlenebilmektedir (10).

Primer ve metastatik hastalığı ayırt etmek önemli ancak ayrımı yapmak her zaman mümkün değildir. Primer kutanöz lezyon yokluğu, soliter kitle, in-situ odak varlığ primer mukozal melanom olarak yorumlanabilir (6,11). Otopsi serilerinde malign melanom hastalarında gastrointestinal sistem metastazı $\% 60$ oranında görülürken hastaların yalnızca \%1-4 kadarında masif gastrointestinal kanama, perforasyon, anemi, kramp, kronik abdominal ağrı, kilo kaybı gibi gastrointestinal semptom görülür $(4,6)$. En s1k görülen semptom ise obstrüksiyondur (6).

Gastrointestinal malign melanomların tanısında endoskopi ve radyoloji önemlidir (6). Tanida abdominal ultrasonografi, Baryumlu grafi, endoskopi, bilgisayarlı tomografi(BT) ve pozitron emisyon tomografisi (PET) kullanılabilmektedir (6).

Primer intestinal melanomlarda ve intestinal metastatik melanomlarda geniş cerrahi rezeksiyon primer tedavidir. Metastatik melanomda cerrahi tedavi etkili palyatif tedavi yöntemidir. Ancak dissemine hastalıkta agresif cerrahi önerilmemektedir. Metastatik hastalıkta sistemik tedavide kemoterapi, radyoterapi, immünoterapi ve biokemoterapi rejimleri veya kombinleri denenebilir. İnce barsağın primer melanomlarında sistemik adjuvan kemoterapinin rolü sınırlı olup düşük yanıt oranı mevcuttur (6). 


\section{MATERYAL-METOD}

$\mathrm{Bu}$ çalışmada Ankara Yıldırım Beyazıt Üniversitesi Atatürk Eğitim ve Araştırma Hastanesi Patoloji ABD 2006-2015 y1llar1 arasında tanı almış 85 adet malign melanom olgusu retrospektif olarak incelenmiştir. Gastrointestinal mukozal melanom olgularına ait $\mathrm{H} \& \mathrm{E}$ kesitler incelenmiş ve canlı tümör alanı \%50'nin üzerinde olacak şekilde tümör alanları işaretlenerek parafin kesitler alınmıştır. Deparafinizasyon ve DNA izolasyonundan sonra BRAF V600-E mutasyon analizi yapılmıştır.

\section{BRAF-V600E mutasyon analizi:}

Her olgu için 2'şer adet olmak üzere PCR reaksiyon karışımı $15 \mu 1$, primer mikst $6 \mu 1$, molecular grade water $8 \mu \mathrm{l}$ ve daha önce Invitrogen PureLink Genomic DNA izolasyon kiti ile izole edilen DNA örnekleri $(50 \mathrm{ng} / \mu \mathrm{l})$ kullanılmıştır. Daha sonra $95^{\circ} \mathrm{C}$ 'de 10 dakika, $95^{\circ} \mathrm{C}^{\prime}$ de 30 saniye, $64^{\circ} \mathrm{C}$ 'de 60 saniye $4 \mathrm{kez}$ sıcaklık tablosu uygulanmıştır.

Elde edilen mikstlerden Applied Biosystems Step One Plus Real Time PCR (Forecity, CA, USA) platformu ve Entrogen BRAF Mutation Analysis Kit (Tarzana, CA, USA) kullanilarak pozitif ve negatif kontroller eşliğinde BRAF-V600E mutasyon varlığ araştırılmıştır.

PCR kurulumunda BRAF pozitif kontrol olarak Reporter FAM Floresan ve endojen kontrol olarak Reporter VIC ile işaretli problar kullanılmıştır. Negatif kontrol olarak nuclease free water kullanılmıştır. Analiz sonucunda BRAF 600. Kodonda GTG $>$ GAG değişiminde timinin yerini adeninin alması ile valin aminoasidinin yerine glutamat aminoasidi ile değişmesine neden olan BRAFV600E mutant geni tespit edilmiştir.

\section{BULGULAR}

Mukozal Malign Melanom tanıs alan 14 olgunun 6's1 gastrointestinal yerleşimli idi Olgular 54-84 yaş aralığında olup 2'si kadın 4'ü erkekti. Gastrointestinal melanomların 4'ü rektum, 2'si ince barsak yerleşimliydi.

Rektum lokalizasyonlu malign melanom olgularında sistemik taramalarda primer odak saptanmadı. İnce barsak yerleşimli olan 2 olguda tümör iki odakta izlendi (Resim 1) Yapılan sistemik taramalarda primer odak saptanmadi. İnce barsak lokalizasyonlu bir olguda omentum metastazı da mevcuttu. İnce barsak yerleşimli bu iki olgu metastaz lehine değerlendirildi.

Olguların takip süreleri 2 ay ile 48 ay arasında değişmekteydi. Tanıdan sonraki ilk 6 ay içerisinde 3 adet rektum yerleşimli ve 1 adet ince barsak yerleşimli mukozal melanom olgusu eks olmuştur. İnce barsak yerleşimli diğer olgu ise 4 yıl sonra eks olmuştur. Rektum yerleşimli 1 melanom olgusu 10 ay takip süresi sonunda hala hayatta idi (Tablo1).

Olguların tamamında PCR yöntemi ile çalışılan BRAF-V600E mutasyonu yalnızca ince barsak yerleşimli ve omentum metastazı olan çok odaklı melanom olgusunda izlenmiştir (figür 1). Gastrointestinal yerleşim dış1 8 olgunun 6'sı baş-boyun kökenli mukozal malign melanomdu. Diğerleri ise vulva ve mesane yerleşimliydi (Tablo 2). 
Tablo 1: GİS melanom olgularının klinik özellikleri

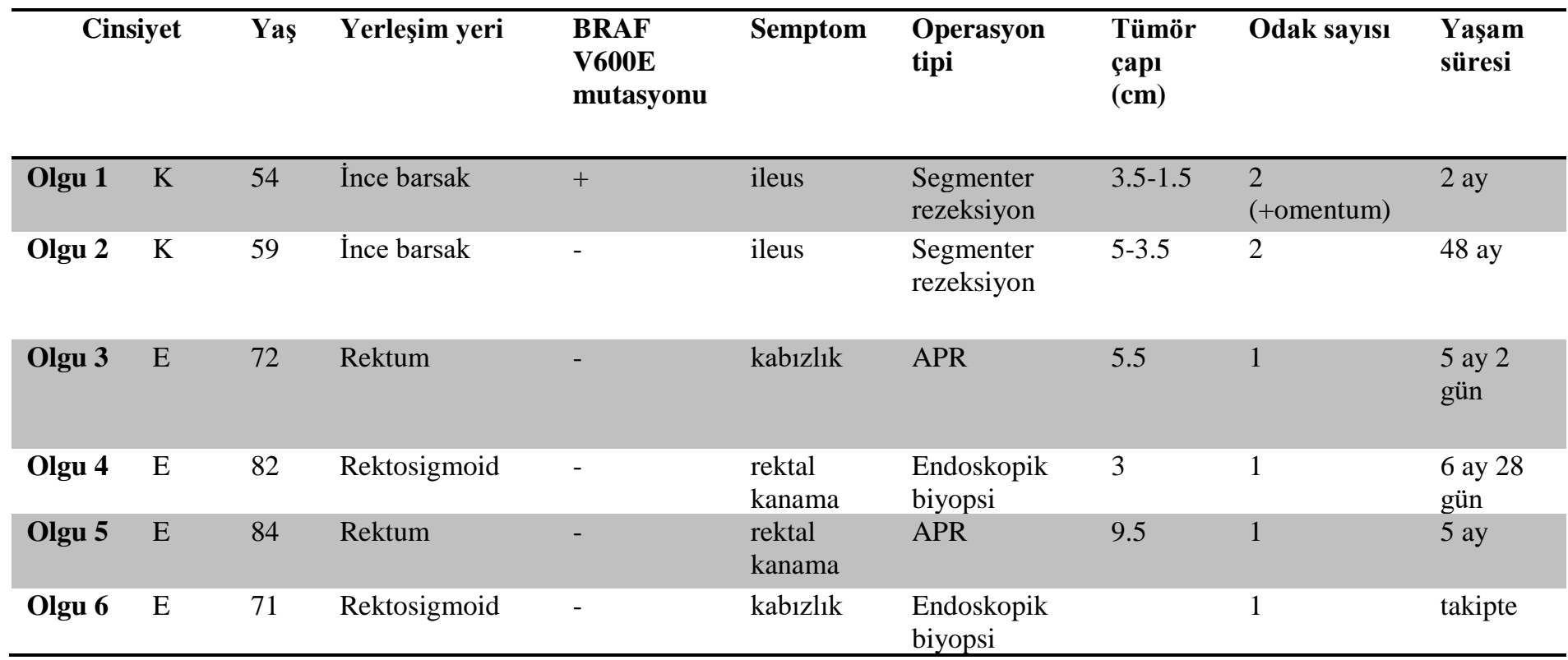

APR: Abdominoperineal rezeksiyon

Tablo 2: GIS dışı mukozal malign melanom olgularının lokalizasyon, yaș ve cinsiyet dağılımı

\begin{tabular}{lllll}
\hline Olgu & Lokalizasyon & Sayı(n) & Yaş & Cinsiyet \\
\hline & & & & \\
1 & Vulva & 1 & 68 & Kadın \\
2 & Mesane & 1 & 59 & Erkek \\
3 & Göz & 1 & 63 & Erkek \\
4 & Göz & 1 & 65 & Kadın \\
5 & Nazofarenks & 1 & 65 & Kadın \\
6 & Göz & 1 & 62 & Erkek \\
7 & Bukkal mukoza & 1 & 78 & Kadın \\
8 & Göz & 1 & 80 & Erkek \\
\hline \hline
\end{tabular}

$1 \mathrm{~A}$
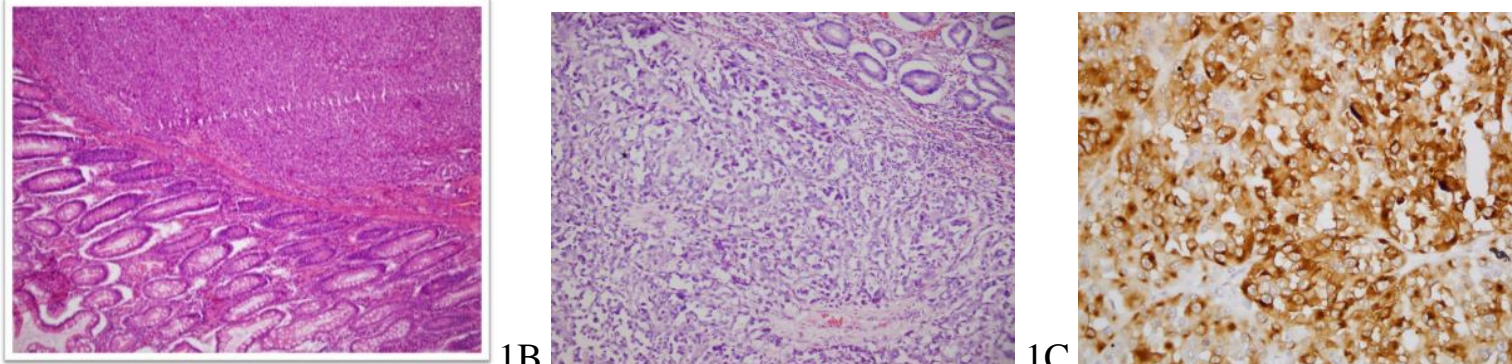

Resim 1A: İleum mukozası altında malign melanom (H\&E X100)

Resim 1B: İri, pleomorfik, veziküler nükleuslu hücrelerle karakterli solid tümör (H\&E X200)

Resim 1C: Tümör hücrelerinde kuvvetli HMB-45 pozitifliği

Adress for correspondence: Ankara Yıldırım Beyazıt Üniversitesi, Atatürk EAH, Patoloji Bölümü, Eskişehir yolu, No: 2 Bilkent Ankara - Türkiye

e-mail: hayriyetatli@gmail.com

Available at www.actaoncologicaturcica.com

Copyright $\odot$ Ankara Onkoloji Hastanesi 


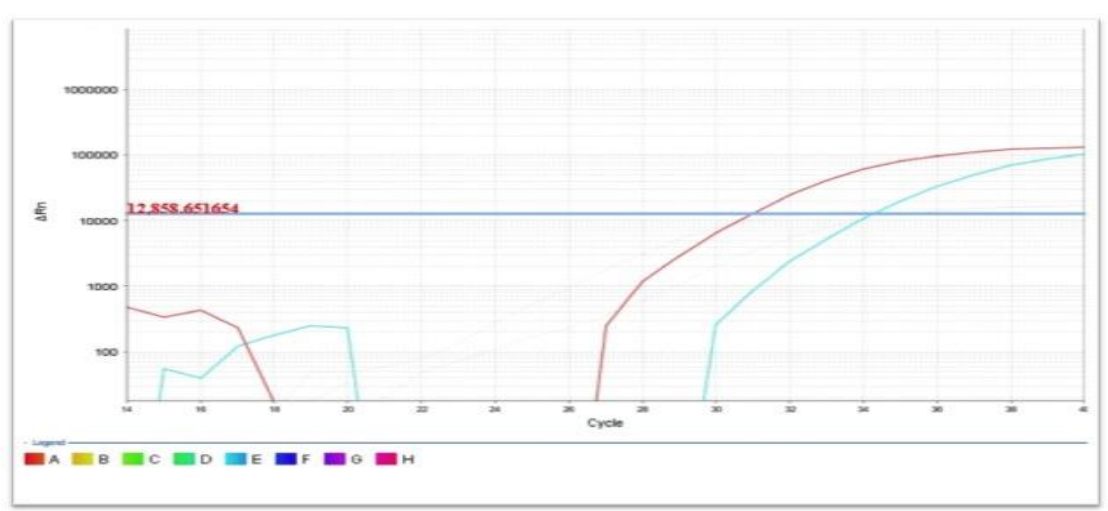

Figür 1: Gerçek zamanlı PCR yöntemi ile BRAF V600E mutasyonu

\section{TARTIŞMA}

Melanomlar gastrointestinal sisteme en sik metastaz yapan tümörlerdir. Kutanöz ve oküler lezyonların metastazları gastrointestinal sistemde sıkça görülür. Primer mukozal melanomlar ise oldukça nadirdir (11).

Primer intestinal melanomlar agresif davranış ve tanı anında sıklıkla saptanan sistemik metastazları nedeniyle kutanöz melanomlardan daha kötü gidişlidir (6).

Otopsi serilerinde melanomların gastrointestinal sistem metastaz insidans1 \%68 karaciğer, \%58 ince barsak, \%22 kolon, \%20 mide, \%12 duodenum, \%5 rektum, \%4 özefagus ve \%1 anüs olarak bildirilmiştir (11). Bizim çalışmamızda metastatik olduğu düşünülen 2 ince barsak yerleşimli mukozal melanom olgusu mevcuttu.

Mukozal melanom insidansı yaşla birlikte artmaktadır (5). Mukozal melanom olgularında hastaların \%60'1 65 yaş üzeri olup $\% 3$ 'den az hasta 30 yaş altıdır (5). Bizim çalışmamızda olguların \%66,6's1 65 yaş üstünde idi.

Mukozal melanomlar ortalama 10-13.4 ay yaşam süresine sahiptirler (12). Bizim serimizde ortalama yaşam süresi 12,8 aydır. Çalışmamızda ilk tanı sonrası takipte 10. ayda olan olgu dişında yaşayan olgu bulunmamaktadır.

Literatürde ince barsak yerleşimli primer mukozal melanomlara ait oldukça az sayıda çalışma bulunmaktadır. Bizim çalışmamızda 2 ince barsak yerleşimli melanom olgusu mevcuttu. $\mathrm{Bu}$ olguların biri kadın diğeri erkek cinsiyette olup yaşları sirasiyla 59 ve 54 'dür.

Tüm olgulara uygulanan BRAFV600E mutasyonunu saptamaya yönelik PCR sonucunda ince barsak yerleşimli bir mukozal melanomda BRAF-V600E mutasyonu saptanmıştır. Çok odaklı tümöre sahip ve eş zamanlı omental metastaz içeren bu olgu tanıdan 2 ay sonra ex olmuştur. Diğer ince barsak yerleşimli melanom olgusunun yaşam süresi 48 aydır.

Anorektal melanomlar sik görülmemekte ve her yıl milyonda 1-2 yeni olgu saptanmaktadır (11). Bizim serimizde rektum yerleşimli 4 olgu mevcuttur. Anorektal yerleşimli melanom olgularının \%50'si 70 yaşın üzerindedir (5). Literatürde her iki cinsiyetin eşit etkilendiği bildirilmiştir (11). Çalışmamızda erkek cinsiyet hakim olup olguların üçü erkek biri kadın idi. Rektum yerleşimli olgular 70 yaş üzerindeydi.

Melanomlar oldukça heterojen bir grup tümör olup mukozal ve kutanöz melanomlar farklı genetik yolaklar içerirler $(3,4,7)$. Yeni çalışmalar melanom genetiği üzerine yoğunlaşmaktadır. Kutanöz melanomlarda en s1k BRAF (serin/treonin kinaz) ve NRAS mutasyonu görülür $(3,5,7,10)$. BRAF $7 q$ 34'de lokalize MAPK (mitojen aktive edici protein kinaz) yolağının üyesi bir serin/treonin kinazdır (8). En sık BRAF-V600E mutasyonu izlenirken ardından \%10-30 oranında BRAFV600K mutasyonu, \%3 oranında V600D/R mutasyonu görülür (9). BRAF-V600E mutasyonu melanom hücrelerinde ERK aktivitesini sağlayarak hücrelerin kontrolsüz proliferasyonunu ve surveyini etkiler (7). 
Mukozal melanomlarda bir reseptör tirozin kinaz olan kit mutasyonu görülmektedir (\%23) $(10,11)$. Kit melanosit proliferasyonunda ve gelişiminde rol almaktadır. Kit mutasyonu genellikle jukstamembranöz domaini kodlayan bölgede görülür böylece MAPK ve PIK3CA gibi hedef genler aktive olur. Yeni çalışmalar kit mutant melanositlerin metastaz kapasitesinin daha fazla olduğunu göstermiştir $(6,12)$.

Uzun yaşam süresi geniş rezeksiyon yapılan olgularda bildirilmiştir (11). Rektal yerleşimli mukozal melanom olgularının 2'sinde abdominoperineal rezeksiyon(APR) uygulanmıştır. $\mathrm{Bu} 2$ olguda ortalama yaşam süresi 5 aydır. Ortalama yaşam süresi 4-6 ay kadardır. Bizim serimizde 1 olguda BRAFV600E mutasyonu saptanmış ve bu olgunun yaşam süresi 2 aydır.

\section{SONUÇ}

Bizim çalışmamızda kliniğimizde mukozal melanom tanısı almış 6 olguda BRAF-V600E mutasyonu varlığı araştırılmıştır. Mutasyon varlığı, primer hastalık ilişkisi ve klinik özellikler incelenmiştir.

Çalıșmamızda literatürle uyumlu olarak BRAF-V600E mutasyonu var olan tek vaka multi odak yerleşimli olup bu olguda klinik

\section{Referanslar}

1. Absence of BRAF mutations in UV-protected mucosal melanomas. Edwards RH, Ward MR, Wu H et al. J Med Genet 2004; 41:270-272. Doi:10.1136/jmg.2003.016667

2. Primary localization and tumor thickness as prognostic factors of survival in patients with mucosal melanoma. Mehra T, Grözinger G, Mann S et al. PLoS ONE. 2014;9 (11): e112535. Doi:10.1371/journal.pone.0112535

3. Update on primary mucosal melanoma. Tacastacas JD, Bray J, Cohen YK, Arbesman J, Kim J, Koon HB. J Am Acad Dermatol. 2014; Aug; 71(2): 366-75.

4. Malignant melanoma of the gastro-intestinal tract: A case series. Patel K, Ward S.T, Packer $\mathrm{T}$ et al. International Journal of Surgery. 12(2014):523-27.

5. Primary mucosal melanomas: a compherensive review. Mihajlovic M, Vlajkovic S, Jovanovc P, Stefanovic V. Int J Clin Exp Pathol. 2012; 5(8):739-753. olarak mukozal metastaz düşünülmekteydi. Diğer olgularda mutasyon varlığ saptanmamıştır.

Malign melanomlar heterojen bir grup neoplazilerdir. Primer mukozal melanomlar oldukça nadir görülürler. Kutanöz ve oküler melanomların mukozal metastazı oldukça siktır. Otopsi serilerinde kutanöz melanom olgularının gastrointestinal metastazı \%60'a varan oranlarda görülebildiği bildirilmiştir. Ancak primer melanomları saptamak her zaman kolay değildir. Bununla birlikte tedavi modaliteleri açısından önem taşımaktadır (13). Özellikle hedefe yönelik tedavide c-kit mutasyonu olanlarda tirozin kinaz inhibitörü imatinib tedavisi rezeke edilemeyen melanomlarda fayda sağlamaktadır (14). BRAF V600 mutasyonu olan metastatik melanomlarda ise Vemurafenib ile hedefe yönelik tedaviye olumlu yanıt alınmaktadır (15). Tedavi seçimi ve prognozu etkileyen tümörün yerleşim yeri, histopatolojik özellikleri yanısıra moleküler ve genetik özelliklerinin de belirlenmesi önem taşımaktadır.

\section{Conflict of interest: None}

6. Melanomas of the small intestine. Lens $M$, Bataille V, krivokapic Z. Lancet Oncol. 2009; 10: 516-21.

7. Oral malignant melanoma: A report of two cases with BRAF molecular analysis. Soma PF, Pettinato A, Agnone AM et al. Oncology Letters. 2014;v8:1283-1286.

8. C-kit gene mutation and CD117 expression in human anorectal melanomas. Ni S, Huang D, Chen X, Huang J, Kong Y, Xu Y et al. Human Pathology. 2012; 43: 801-807.

9. Prospective immunohistochemical analysis of BRAF V600E mutation in melanoma. Thiel A, Moza M, Kytölä S et al. Human Pathology. 2015; 46: 169-175.

10. NRAS and BRAF mutation frequency in primary oral mucosal melanoma. Buery RR, Sİar CH, Katase N, Gunduz M, Lefeuvre M, Fukii M Oncology Reports. 2011; 26: 783-787.

11. Primary and metastatic diseases in malignant melanoma of the gastrointestinal tract. Schuchter LM, Green R, Fraker D. Curr. Opin. Oncology. 2000; 12:181-185. 
12. Endoscopic and pathologic findings associated with clinical outcomes of melanoma in the upper gastrointestinal tract. Ahn JY, Hwang S, Park YS, Kim HR, Jung HY, Kim JH An Surg Oncol. 2014; 21:2532-2539.

13. Prognostic and predictive values of oncogenic BRAF, NRAS, c-KIT and MITF in cutaneous and mucous melanoma. Pracht M, Mogna A, Lespagnol A, Fautrel A, Mouchet N, Gall FL. J Eur Acad Dermatol Venereol. 2015 Aug;29(8):1530-8.
14. A phase 2 trial of dasatinib in patients with locally advanced or stage IV mucosal, acral, or vulvovaginal melanoma: A trial of the ECOGACRIN Cancer Research Group (E2607). Kalinsky K, Lee S, Rubin KM et al. Cancer. 2017 Jul 15;123(14):2688-2697

15. Vemurafenib in patients with BRAFV600 mutation-positive metastatic melanoma: final overall survival results of the randomized BRIM-3 study. Chapman PB, rOBERT c, Larkin J, Ann Oncol. 2017 Oct 1;28(10):25812587. 